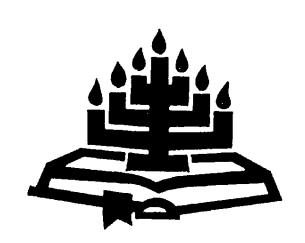

\title{
Constructing the rights and duties of slave-owners as socio-historic context of the New Testament
}

\author{
H. Goede \& F. Janse van Rensburg
}

School of Biblical Studies \& Ancient Languages

Potchefstroom Campus

North-West University

POTCHEFSTROOM

E-mail: Hennie.Goede@nwu.ac.za

Fika.JanseVanRensburg@nwu.ac.za

\begin{abstract}
Constructing the rights and duties of slave-owners as sociohistoric context of the New Testament
\end{abstract}

This article aims to construct the rights and duties of slaveowners in antiquity as part of the socio-historical context of the New Testament. In order to achieve this aim, the primary sources referring to Greek, Roman and Jewish law of slavery will first be described. Three aspects of the law of slavery, namely legal definitions of freedom and slavery, the legal status of slaves, and the rights of slave-owners are investigated in Greek, Roman and Jewish law. Relevant texts from these sources are then identified, analysed and interpreted. The results of this process of analysis and interpretation are used to construct the legal context within which the exhortations directed at slave-owners in the New Testament should be read. We submit that Jewish law provided a sound alternative legal and religious context to the writers of the New Testament addressing Christian slave-owners. This alternative context functioned as a counterweight to the strict legal contexts provided by Greek and Roman law.

\section{Opsomming}

'n Konstruksie van die regte en verpligtings van slaweeienaars as 'n sosio-historiese konteks van die Nuwe Testament

Hierdie artikel het ten doel om die regte en verpligtings van slawe-eienaars in die antieke tyd te konstrueer as onderdeel 
van die sosio-historiese konteks van die Nuwe Testament. Ten einde hierdie doel te bereik, word die primêre bronne van Griekse, Romeinse en Joodse reg eerstens beskryf. Drie aspekte van die reg op slawerny word in Griekse, Romeinse en Joodse reg ondersoek, naamlik regsdefinisies van vryheid en slawerny, die regstatus van slawe en die regte van slaweeienaars. Relevante tekste uit hierdie bronne word vervolgens geïdentifiseer, geanaliseer en geïnterpreteer. Die resultate van hierdie proses van analise en interpretasie word gebruik om die regskonteks waarbinne die oproepe tot slawe-eienaars in die Nuwe Testament gelees moet word, te konstrueer. Ons doen aan die hand dat Joodse reg 'n gegronde alternatiewe regs- en godsdienstige konteks vir die skrywers van die Nuwe Testament gebied het waarbinne met Christen slawe-eienaars gepraat is. Hierdie alternatiewe konteks het as 'n teenwig gefunksioneer teen die streng regskontekste van die Griekse en Romeinse reg.

\section{Introduction}

This article aims to construct the rights and duties of slave-owners in antiquity as part of the socio-historic context of the New Testament. In order to achieve this aim, the primary sources referring to Greek, Roman and Jewish law of slavery are first described. Three aspects of the law of slavery, namely legal definitions of freedom and slavery, the legal status of slaves, and the rights of slave-owners are investigated in Greek, Roman and Jewish law. Relevant texts from these sources are then identified, analysed, and interpreted. The results of this process of analysis and interpretation are used to construct the legal context within which the exhortations directed at slave-owners in the New Testament should be read. This construction of the legal context may provide clues, if not evidence, that the authors of the New Testament relied on Jewish law as a sound alternative legal and religious context when addressing Christian slave-owners, and that this alternative context functioned as a counterweight to the strict legal contexts provided by Greek and Roman law.

Although this study focuses on the legal rights and duties of slaveowners, it is necessary to consider the rights and especially duties of slaves. Rights and duties represent two sides of the same coin. When two parties for example conclude a contract, one party must deliver the performance as stipulated in the agreement (the duty) and the other party is entitled to claim such performance by legal process (Borkowski \& Du Plessis, 2005:251). For every legal duty there is a corresponding legally enforceable right. Thus a survey of 
the duties of slaves will also constitute a list of rights of owners, and vice versa.

\section{General development and characteristics of Greek, Roman and Jewish law}

\subsection{Greek law ${ }^{1}$}

What is the relevance of Greek law to this study? In respect of the sale of slaves in the Roman world, Pringsheim (1950:481, 483) states that "[t]he Greek notaries did not merely ignore Roman law, but openly rejected it", showing "tough resistance of popular Greek conceptions to Roman influence". He bases his argument on the fact that the eastern provinces of the Roman Empire rejected Roman law especially with regard to the sale of slaves. Whereas Roman law offered protection for the purchasers of slaves against latent defects, Greek law limited such protection. Bartchy (1973:40) concludes in his study of 1 Corinthians 7:21 that many slaves (at least in Corinth) lived under Greek law. This should not be surprising since the eastern part of the Roman Empire preserved the Greek language and the products of classical Greek literature and science (Kelly, 1992:82). There is little reason to believe that this legacy did not include Greek law.

As far as Greek law of slavery is concerned, the laws served three purposes that were at least partly contradictory (Fisher, 1993:58):

- The maintenance and reinforcement of the fundamental distinction between slave and free;

- the preservation of slavery as institution, allowing owners a great deal of control over their slaves; and

- same legal protection for slaves by delimiting the powers of owners over their slaves to some extent.

\subsection{Roman law}

The inherent spirit of Roman law is best considered through the eyes of the elite on legal matters, and specifically the jurists (Watson, 1995:34). The enduring characteristics of Roman law were shaped by the struggle between the patricians and the plebeians for

1 For purposes of this study, we consider Calhoun's (1977) discussion of Greek law to be satisfactory augmented by other sources where available. 
control of the Roman Republic established in 509 BC. This struggle culminated in the codification of civil law in the Twelve Tables in 451-450 BC (Borkowski \& Du Plessis, 2005:29). This laid the foundation of the following characteristics of Roman law:

- Religious law was specifically excluded since the rituals of the state religion and the priestly offices were the monopoly of the elite (Watson, 1995:38). This fact lends Roman law its decidedly secular appearance.

- Roman private law exhibits a distinctly egalitarian character since the patricians attempted to appease the plebeians' demands for equal rights of liberty (Watson, 1995:38). This egalitarianism was, however, an illusion for the fundamental distinction between freeborn and slave governed private law. The law would always retain an element of aristocracy (Watson, 1995:40).

- Roman jurists exhibited a form of legal logic and interpretation removed from particular political, social, and economic reality (Watson, 1995:39). Legal opinions and judgments were not formulated on the basis of reasonableness, economic advantage, usefulness, or justice.

- Roman law was recognisably the same at around $200 \mathrm{BC}$, during the Republic and Principate, and even in the time of Justinian's codification in the sixth century AD (Watson, 1995:41). This characteristic is true for the whole of Roman private law, including the law of slavery.

- The evidence points to the widespread application of Roman law throughout the empire (Johnston, 1999:11). Yet the evidence falls short of proving any uniform application thereof in the provinces.

This is then the general legal context of the Roman law of slavery which infiltrated every aspect of Roman private law. In the words of Crook (1984:55): "[t]here can be scarcely a title of the Digest in which he [a slave] does not figure".

\subsection{Jewish law}

The fundamental norm of Jewish law is that everything set forth in the Torah is binding on the Jewish legal system (Elon, 1994:232). The source for the authority of the Torah is the Ruler of the universe, the Giver of the law to Moses at Sinai. Jewish law is thus religious in that its root source is divine revelation (Elon, 1994:4). Religious and 
non-religious laws are found in the same divinely revealed sources. The Ten Commandments illustrates the point. Alongside a commandment on the observance of the Sabbath, one finds the commandment not to steal. This distinguishes Jewish law from Greek and Roman law, both of which developed into secular legal systems. Because of the religious nature of Jewish law, its sources were interpreted exegetically (Elon, 1994:283ff). For this purpose the thirteen canons of interpretation and other exegetical rules were formulated (Elon, 1994:318-319).

The law considered particularly divine by the Jewish people are the Ten Commandments (Zane, 1998:87). These laws are legal, religious, or moral in nature. No penalties are prescribed, apart from the threat of evil consequences for non-compliance. These consequences often involve the whole community rather than only guilty individuals. The Ten Commandments do not, except by inference, cover many fields of law, and in these matters Jewish law exhibited great liberality (Zane, 1998:93). The Jewish law of slavery provides an excellent example.

\section{Legal definitions of freedom and slavery}

The first matter to be considered is the legal definition of freedom and slavery.

\subsection{Greek law}

Sammlung der griechischen Dialekt-Inschriften (Westermann, 1959:10)

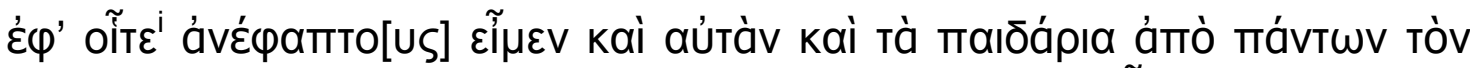

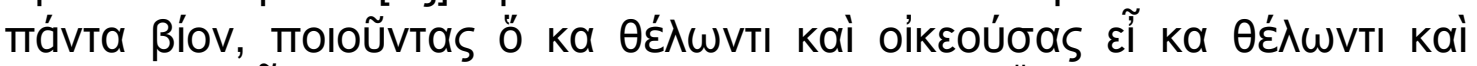

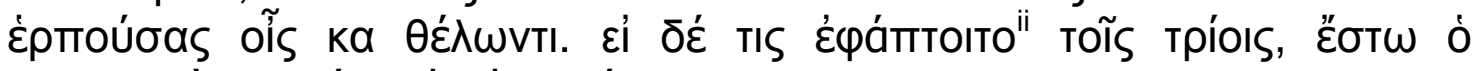

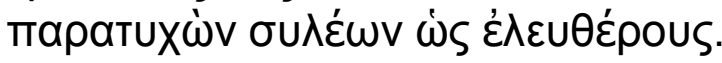

Own translation with grammatical notes:

..., on condition that ' we cannot be reclaimed [having been manumitted] and to doing as he wishes and living where he wishes and going where he wishes. But if someone claims as his property ii in terms of these three, let a chance passerby rescue like a free man.

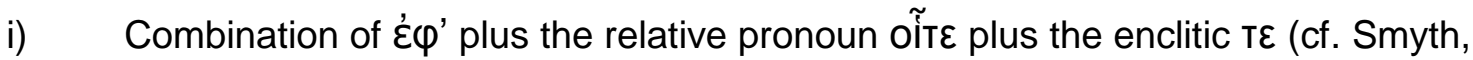
1956:97, 512).

ii) Used as a legal term for claiming something as your property (Liddell et al., 1996). 


\section{Context:}

This passage dates from 170-157/6 BC (Westermann, 1959:10). It is an excellent example of statement of the four elements of freedom in Greek thought.

\section{Interpretation:}

Freedom consists of these elements: A free man is not subject to seizure as property; he may do as he wishes; he may go where he wishes. Westermann (1959:26) adds a fourth element: A free man is his own master in all legal matters. By contrast, the opposite would be true of a slave.

\section{Relevance for the exhortations directed at slave-owners in the New} Testament:

A slave would be subject to seizure, limited in his actions and movements, and require a representative in legal proceedings.

\section{Aristoteles: Politica 1253b.32}

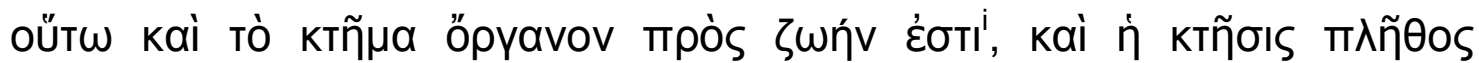

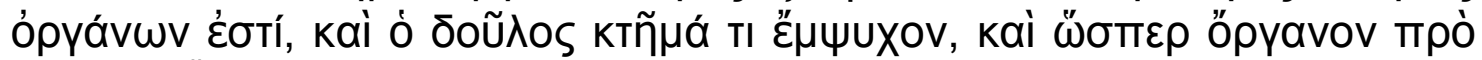

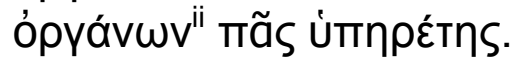

\section{Own translation with grammatical notes:}

Thus a thing possessed also constitutes ${ }^{i}$ a tool for the purpose of [a good] life, and property constitute a number of tools, and a slave is a living thing possessed of the same sort, and every assistant is as it were more of a tool than (other) tools."

i) The present indicative here indicates a general truth (cf. Smyth, 1956:421).

ii) In this context про́ + genitive indicates preference (cf. Smyth, 1956:384).

\section{Context:}

Aristotle's (ca. 435-335 BC) Politica represents typical writings on political theory in ancient Greece and Rome (Nussbaum, 2003a:1206). He provides an

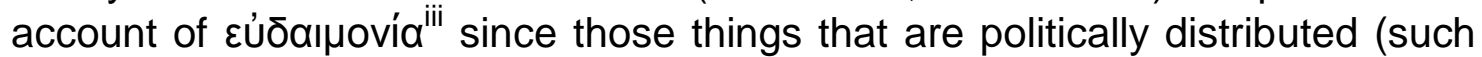
as property and offices) are means to achieve human flourishing. He also considers various regimes in an attempt to identify the best form of government. Aristotle's statements on slaves must therefore first and foremost be considered in a political rather than legal context. This does, however, not necessarily imply that his statements on slavery, such as the one quoted above, are not juridically relevant and/or accurate. The above-quoted definition forms part of a section dealing with household management, and specifically the relationship between slave-owner and slave. 


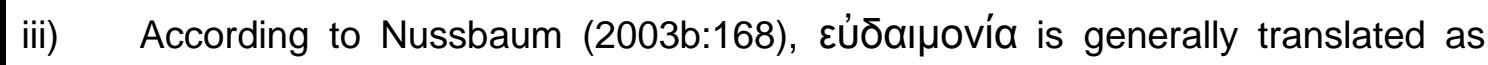
"happiness" but may be more accurately rendered "human flourishing".

Interpretation:

Aristotle identifies the two natures of a slave as property (in this context a tool) and as a human being ("a living thing"). As a tool, its purpose is to provide its owner a good life.

Relevance for the exhortations directed at slave-owners in the New Testament:

The twofold nature of a slave must be accounted for in any interpretation of New Testament passages on slave-owners.

Greek legal definitions clearly indicate the distinctions between free and slave: A free person is not subject to seizure as property, he may do as he wishes, he may go where he wishes, and he is his own person in all legal matters. In stark contrast, a slave is subject to seizure, limited in his actions and movements, and he requires a representative in legal proceedings. According to Aristotle a slave is both property and human being - seemingly irreconcilable extremes.

\subsection{Roman law}

The Roman jurists exhibited a decided lack of interest in definition "for it is seldom that a definition may not be turned upside down" (Justinianus, Digesta 50.17.202).

\section{Justinianus: Institutiones 1.3.pr}

Summa itaque divisio de iure personarum ${ }^{i}$ haec est, quod omnes homines aut liberii sunt aut servi.ii

\section{Own translation with grammatical notes:}

And thus the most important division in the law of persons ${ }^{i}$ is that all people are either free persons ${ }^{\mathrm{ii}}$ or slaves ${ }^{\mathrm{iii}}$.

i) "The law of persons" refers to all institutions influencing the legal status (status) of a person and his capacity to have rights and assume obligations (Berger, 1953:628). These institutions include liberty and slavery, citizenship, family, and marriage.

ii) For a definition of "free" see Inst.1.3.1 below.

iii) For a definition of "slave" see Inst.1.3.2 below. 


\section{Context:}

This sentence appears in the first book dealing with the law of persons. The sentence is preceded by definitions of natural law, civil law, and the law of nations (cf. Justinianus, Inst. 1.2.1.pr 1). This sentence then states the general principle governing the Roman law of persons.

\section{Interpretation:}

Roman private law recognised two principle categories of persons, namely those who are free persons and those who are slaves.

Relevance for the exhortations directed at slave-owners in the New Testament:

When New Testament passages refer to slaves and slave-owners, it is not simply a matter of convenience or social categorisation, but rather a strict legal distinction. The study of the legal context of these passages is thus relevant and necessary.

Freedom is defined as follows:

Justinianus: Institutiones 1.3.1 (cf. Justinianus, Digesta 1.5.4.pr)

Et libertas quidem est, ex qua etiam liberi vocantur, naturalis facultasi eius quod cuique facere libet, nisi si quid aut vi aut iure prohibetur.

\section{Own translation with grammatical notes:}

And freedom, from which the term "freemen" is also derived, is indeed every person's natural capacity to do as he pleases, except if it is prohibited either by force or by law.

i) Facultas refers to "the legal ability to conclude an agreement or to accomplish a valid act" (Berger, 1953:467).

\section{Context:}

This definition of freedom directly follows the general principle stated in 1.3.pr.

\section{Interpretation:}

The Roman law definition of freedom is certainly not unambiguous, for a literal interpretation of the definition would make all persons free since the limitations imposed (at least by law) are applicable to all persons (Buckland, 1908:1). It is clear, however, that the Roman jurists considered freedom, and not slavery, to be man's natural state. This contradicts for example Aristotle who considered some people to be free by nature and others to be unfree by nature (Politica 1255a.1-2). 
Relevance for the exhortations directed at slave-owners in the New Testament:

This definition raises the question as to whether the New Testament authors considered unfree to be a natural state or a state imposed by force or by law.

Conversely, slavery is defined as:

Justinianus: Institutiones 1.3.2-3 (cf. Justinianus, Digesta 1.5.4.1-2)

2. Servitus autem est constitutio iuris gentium ${ }^{i}$, qua quis dominio alieno contra naturamii subicitur.

3. Servi autem ex eo appellati sunt, quod imperatores captivos sii $^{\mathrm{ii}}$ vendere iubent ac per hoc servare nec occidere solent: qui etiam mancipia dicti sunt, quod ab hostibus manu capiuntur. ${ }^{\text {iv }}$

\section{Own translation with grammatical notes:}

2. However, slavery is an institution of the law of nations, ${ }^{i}$ in terms of which one is contrary to the natural order ${ }^{\mathrm{ii}}$ subjected to the ownership of another.

3. Slaves are, however, so called because commanders order captives ${ }^{\mathrm{ii}}$ to be sold and saved in this manner rather than killing them. They are also called mancipia because they are physically taken ${ }^{\text {iv }}$ from the enemy.

i) The "law of nations" refers to the law applied to all peoples, including the Roman people (Berger, 1953:528). It is therefore not in conflict with the law applicable only to Roman citizens or civil law.

ii) Natura refers to "nature of things, natural order, natural reality" (Berger, 1953:591).

iii) Captivus refers to a person (being a Roman citizen or otherwise) who has been captured by the enemy (Berger, 1953:380-381). Such a captive automatically became a slave of the enemy, but Roman citizens regained their legal status upon their return to Rome.

iv) From the Latin manu capi (Watson, 1987:8).

\section{Context:}

This definition of slavery directly follows the general principle stated in 1.3.pr and the definition of freedom in 1.3.1. 


\section{Interpretation:}

The sentence confirms the viewpoint that slavery is not considered to be the natural state of man, but rather a state imposed by the law common to all people. This conflict between law and nature must not be overestimated, since the Romans exhibited a decided lack of interest in an ideal law for Rome (Watson, 1987:7). Sentence 3 does seem to contain a moral justification of slavery arguing that to be sold into slavery is a preferable fate to being killed.

\section{Relevance for the exhortations directed at slave-owners in the New Testament:}

This definition also raises the question as to whether the New Testament authors considered unfree to be a natural state or a state imposed by force or by law. Considering sentence 3's apparent justification of slavery, one must ask whether the New Testament authors offered any arguments and/or justifications either in favour of or against slavery.

\section{Justinianus: Digesta 1.1.4}

Ulpianus libro primo institutionum. ... nam quamdiu quis in servitute est, manuil et potestatii suppositus est ...

\section{Own translation with grammatical notes:}

Ulpianus. Institutes. Book 1. ... for as long as someone is in slavery, he is subjected to the power' and authority ${ }^{\text {ii }}$ of another ...

i) Manus refers to the power of the family head over all the members and slaves of the family (Berger, 1953:577).

ii) Potestas refers to the authority that an owner has with regard to his possessions, including his slaves (Berger, 1953:640). It may also refer to an owner's physical power over his slaves.

\section{Context:}

This fragment belongs to the title dealing with justice and law. The title provides a number of legal definitions. It specifically defines the law of nations and lists some elements of law derived from it, including slavery.

\section{Interpretation:}

This fragment states the essence of slavery as a legal institution, namely that a slave is subjected to the power and authority, even in a physical sense, of his owner. This subjection places a slave on par with any material possession, although the person of a slave is recognised in the fact that slaves are considered to be part of the family unit. 
Relevance for the exhortations directed at slave-owners in the New Testament:

References to slaves in the New Testament carry the implication of that person's subjection to another and all the legal consequences flowing from the fact.

Roman law adds a caveat to the Greek definition of freedom, namely that a free man's freedom is restricted by law. Slavery is defined in terms of the slave's subjection to the power and authority of his owner.

\subsection{Jewish law}

According to the Mishnah, Israelite society was divided into four categories: householders (or slave-owners), minor sons, both minor and adult women, and slaves (Flesher, 1988:2). The first three categories are defined in terms of their natural characteristics such as age, gender and capacity to reason, but the last category is defined in terms of external factors. The slave's inherent characteristics, being the same of those of free persons, have no bearing on his status. His status is rather determined by his relationship to his owner (Flesher, 1988:2).

The compilers of the Mishnah built their concept of slavery on the foundations of the Old Testament (Flesher, 1988:11). They considered Scripture and its picture of slavery as a unified whole, though not all sections as necessarily of equal value (Flesher, 1988:12). As a result, all but one of the Scripture passages to which the Mishnah refers, occur in one of three law codes: The Covenant Code (Ex. 20:22-23:33), the Holiness Code (Lev. 17-26), and the Deuteronomic Source (Deut. 12-26).

M. Hor. 3:8

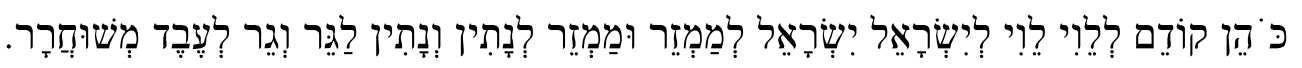

Own translation with grammatical notes:

A priest takes precedence over a Levite, a Levite over an Israelite, an Israelite over an illegitimate child, an illegitimate child over a temple slave, a temple slave over a non-Israelite [alien], a non-Israelite over a freedman [freed slave]. 


\section{Context:}

This section of the Mishnah deals with erroneous decisions and their effects in respect of the provisions of Leviticus 4 and 5 .

\section{Interpretation:}

The passage clearly establishes a hierarchy of social classes in which slaves do not feature, excepting temple slaves (cf. Hezser, 2005:45).

Relevance for the exhortations directed at slave-owners in the New Testament:

Slaves were not considered part of society at large, but belonged to the category of property.

Jewish law does not provide as clear cut definitions of freedom and slavery as Greek and Roman law. Yet the passage quoted above indicates clearly that slaves (excluding temple slaves) were not in the first place considered as human beings, but rather as property. This can be derived from their exclusion from the classes of society.

\section{The legal status of slaves}

\section{1 Greek law}

Under Greek law, the legal status of slaves was defined as follows:

\section{Plato: Leges 11. 914e}

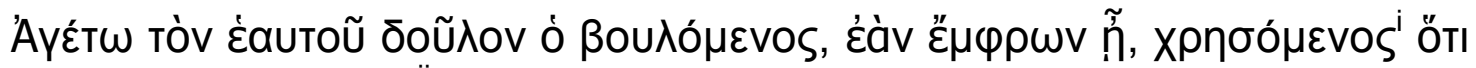

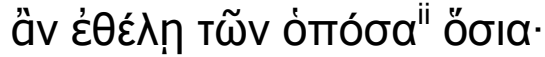

\section{Own translation with grammatical notes:}

Let him who so wishes, provided he is of sound mind, manage his own slave by using ${ }^{i}$ [him] provided he wishes whatever ii is legally permitted.

i) Interpreted as an adverbial participle indicating manner (Smyth, 1956:457).

ii) Use of ómóбoৎ with the definite article as demonstrative (Smyth, 1956:286). This seems to be a feature of Plato's writings. 


\section{Context:}

In his Laws Plato (c. 429-347 BC) deals with social morality as opposed to individual morality (Annas, 2003:1191). He has given up hope that an expert ruler could rule uncorrupted by power, yet maintains that political division and strife can only be overcome by complete obedience to the laws, since the laws are the product of rational reflection. Among these laws we find the one quoted above.

Interpretation:

An owner has absolute authority over his slave within the confines of the law.

Relevance for the exhortations directed at slave-owners in the New Testament:

Owners are addressed in the context of their wide-ranging legal powers with regard to their slaves.

\section{Demosthenes: In Timocratem 167}

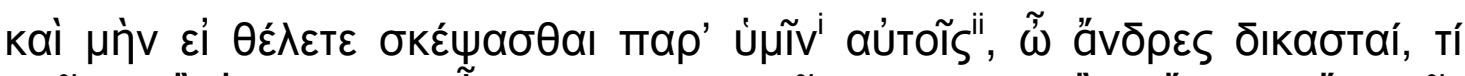

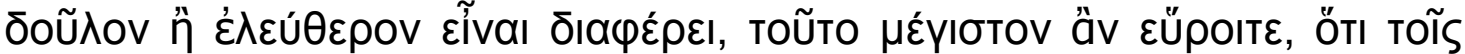

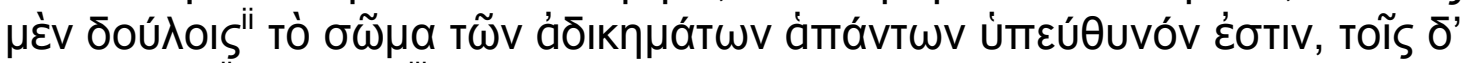

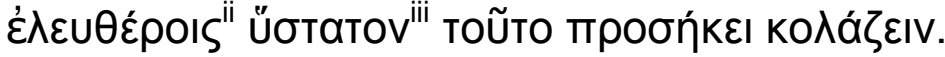

\section{Own translation with grammatical notes:}

Indeed, honourable members of the jury, if you are willing to consider in your judgment ${ }^{i}$ of them ${ }^{\text {ii }}$ what is the difference between being a slave and a freeman, you would find the most important difference: That on the one hand, in the case of slaves, ${ }^{\mathrm{ii}}$ the body is answerable for all their wrongs, but on the other hand, in the case of freemen,"ii this [corporal punishment] is fitting only as punishment of last resort.

i) $\quad$ Пapa + dative indicating the person(s) judging (cf. Smyth, 1956:382).

ii) Dative of relation denoting the persons to whose case the statement is limited (cf. Smyth, 1956:344).

iii) Adverbial accusative of measure and degree (cf. Smyth, 1956:361).

\section{Context:}

Demosthenes (384-322 BC) was the greatest of the Athenian orators (Cawkwell, 2003:456). He was renowned for his private speeches in the law courts of Athens. These letters contain excerpts from the laws of Athens, such as the one quoted above. 


\section{Interpretation:}

Slaves were subjected to corporal punishment whilst freemen were seldom subjected thereto (cf. Harrison, 1968:167). One may also deduce that owners of slaves were entitled to physically punish their slaves. It seems probable that slaves had very little if any recourse in law against their owners for physical abuse (Harrison, 1968:172).

Relevance for the exhortations directed at slave-owners in the New Testament:

Slaves in the New Testament were probably subjected to corporal punishment.

\section{Homer: Iliad 7.472-475}

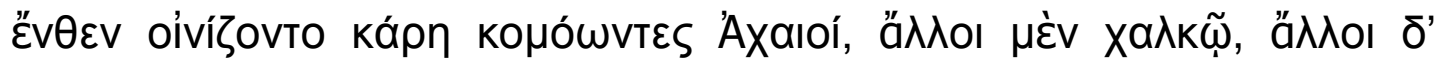

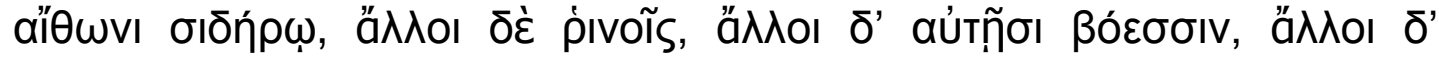

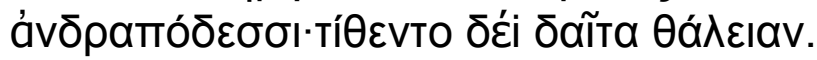

Own translation with grammatical notes:

Thus the long-haired Greeks bartered for wine, some in exchange for bronze, others for iron objects, others for animal skins, others for whole cattle, others for slaves. Then they prepared a plentiful banquet.

\section{Context:}

Iliad was written in approximately the middle of the eight century BC by the poet Homer, according to ancient tradition (Willcock, 2003:718). The poem records a few weeks of fighting during the Trojan War.

\section{Interpretation:}

This passage clearly indicates that slaves were considered property for purposes of trade and commerce (cf. Harrison, 1968:228-230). Thus slaves could be bought, sold, hired, bequeathed, or donated (MacDowell, 1978:80). According to general principles of Athenian property law, two or more persons could be co-owners of a slave (Harrison, 1968:238). Yet Athenian law also recognised to a limited extent the humanity of slaves, deeming his relationship with his owner to be personal.

Relevance for the exhortations directed at slave-owners in the New Testament:

In passages referring to slaves and owners, their relationship must be considered as one of an owner (or owners) in relation to his (or their) property. 
In terms of Greek law, a slave was considered property first and foremost, to be dealt with as property. Consequently, a slave-owner had complete power and authority over his slave. The slave's humanity was considered almost as an afterthought, with very few legal consequences.

\subsection{Roman law}

Under Roman law, the legal status of slaves was defined as follows:

\section{Gaius: Institutiones 2.14a}

Est etiam alia rerum divisio: Nam aut mancipi sunt aut nec mancipi. Mancipi sunt velut fundus in Italico solo, item aedes in Italico solo, item servi et ea animalia quae collo dorsove domari solent, velut boves equi muli asini ...

\section{Own translation with grammatical notes:}

There is, however, also another division of things: For they are either mancipi ${ }^{i}$ or not mancipi. Mancipi are, for instance, land on Italian soil, likewise buildings on Italian soil, likewise slaves and those animals that are commonly broken in for draught or burden, such as oxen, horses, mules, and asses.

i) Mancipium (or mancipatio) refers to "a formal, legal purchase of anything, conferring full power of possession" (Simpson, 1959:360). It entails "a sort of imaginary sale" (Gaius 1.119; cf. Berger, 1953:573). Res mancipi are things of which ownership is only transferable by the solemn act of mancipatio (Berger, 1953:678). Res mancipi represented things and rights that were considered to be the most valuable in primitive rural economies (Gaius 1.120; Watson, 1987:47).

\section{Context:}

Book 2 deals with the law of property. Sentences 1-21 deal with the classification of things.

\section{Interpretation:}

This sentence is clear on the fact that slaves were first and foremost considered to be things or property rather than persons. Yet the classification of slaves as mancipi indicated their value and worth to their owners and society in general.

Relevance for the exhortations directed at slave-owners in the New Testament:

When slaves are mentioned in the New Testament, one must realise that legally speaking they were first considered as property and then as persons. 
Justinianus: Institutiones 2.1.37 (cf. Justinianus Digesta 5.3.27.pr; 6.1.16.pr; 47.2.48.6)

In pecudum fructu etiam fetus est, sicuti lac et pilus et lana: itaque agni et haedi et vituli et equuli statim naturali iure dominii sunt fructuarii. Partus vero ancillae in fructu non est itaque ad dominum proprietatis pertinet: absurdum enim videbatur hominemi in fructu esse, cum omnes fructus rerum natura hominum gratia comparavit.

\section{Own translation with grammatical notes:}

Also, offspring is the fruit of the flock, as are the milk, hair and wool. Thus, according to natural law, lambs, kid-goats, calves, and colts at once become the property of the usufructuary. Nevertheless, the offspring of a female slave are not fruits and thus belong to the owner of the property, for it seems absurd that a person ${ }^{i}$ should be fruit, since all the fruit of things were provided for the benefit of mankind.

i) Homo refers to a human being, whether free or slave (Berger, 1953:488).

\section{Context:}

This sentence belongs to a title dealing with the classification of things. According to the classification, slaves belong to the category of property that can be owned by individual persons. The specific sentence (along with 36 and 38) deals with the situation where one person holds as usufruct the property of another, and is thus entitled to the fruits of that property.

\section{Interpretation:}

In contrast to the aforementioned sources, this sentence bears out the contradiction in Roman law that slaves are simultaneously regarded as things and persons (cf. Watson, 1987:46; Borkowski \& Du Plessis, 2005:90).

Relevance for the exhortations directed at slave-owners in the New Testament:

The recognition of slaves as not only the things of their owners but also as persons in their own right may be significant as a point of departure for the New Testament writers when writing on the relationship between owners and slaves. 


\section{Justinianus: Digesta 4.5.3.1}

Paulus libro undecimo ad edictum. ... quia servile caput nullum iusii habet ...

Own translation with grammatical notes:

Paul. On the Edict. Book 11. ... a person living in slavery' has no legali ${ }^{\mathrm{il}}$ status $\cdots$

i) Ablative of manner.

ii) In this context ius must be read with caput to refer specifically to the ability to conclude legally valid transactions and to be the subject of rights like legal status or capacity. The Romans did not have a general conception of legal capacity or status (Berger, 1953:379).

\section{Context:}

Title 5 deals with changes in condition or status. Fragment 3 refers to changes in condition at the emancipation of a child and the manumission of a slave. A slave cannot change his own condition since he has no legal status. He only obtains legal status at the time of his manumission.

\section{Interpretation:}

Following from the opinion that slaves are things, they have no legal status.

Relevance for the exhortations directed at slave-owners in the New Testament:

The legal status of slaves in the New Testament is clear: they had none.

The slave's legal status under Roman law was defined clearly: He had no status. A slave was considered property and subject to the almost absolute power and authority of his owner. Again, the slave as a human being was acknowledged almost as an afterthought, with very few legal consequences. 


\subsection{Jewish law}

Under Jewish law, the legal status of slaves was defined as follows:

\section{Exodus 21:2-6 (BHS, 1996)}

$$
\begin{aligned}
& 2 \\
& 3 \\
& 4
\end{aligned}
$$

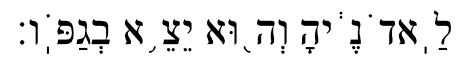

\section{Own translation with grammatical notes:}

2 If you buy a Hebrew servant, he is to serve you for six years. But in the seventh year, he shall go free, without paying anything.

3 If he comes alone, he is to go free alone; but if he has a wife when he comes, she is to go with him.

4 If his master gives him a wife and she bears him sons or daughters, the woman and her children shall belong to her master, and only the man shall go free.

5 But if the servant declares, "I love my master and my wife and children and do not want to go free",

6 then his master must take him before the judges. He shall take him to the door or the doorpost and pierce his ear with an awl. Then he will be his servant for life.

\section{Context:}

This passage forms part of the Covenant Code (Ex. 20:22-23:33); (Flesher, 1988:12). 


\section{Interpretation:}

This passage seems to contain an inherent contradiction. On the one hand it recognises the Hebrew slave as an autonomous individual (cf. Flesher, 1988:18 ff.). The essence of this form of slavery is that the slave contracts out his services for a fixed period (six years in this case), and that he retains his family and social ties existing prior to his entry into slavery. In fact, an Israelite may expressly not treat a fellow-Israelite like a slave (Lev. 25:39). On the other hand, the passage recognises cases where the slave indicates that he (and his family) wishes to remain the property of his owner for the rest of his life. In these cases the slave is marked as such by way of the piercing of the ear, indicating that the slave failed to recognise his deliverance by God (analogous to the deliverance of Israel from slavery in Egypt) and his subsequent obedience to God only and no other human being (cf. Heszer, 2005:45).

Relevance for the exhortations directed at slave-owners in the New Testament:

Jews in the New Testament adhering to the laws of the Old Testament would most probably not have employed fellow Jews, but would rather have bought foreign slaves (see below).

\section{Leviticus 25:44-46 (BHS, 1996)}

44

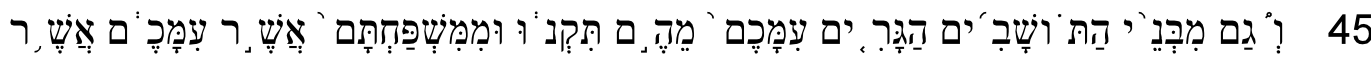

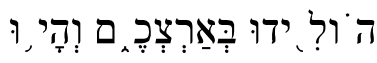

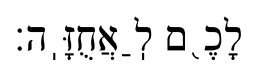

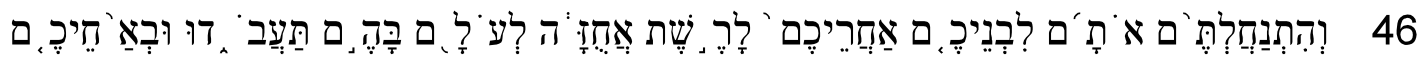

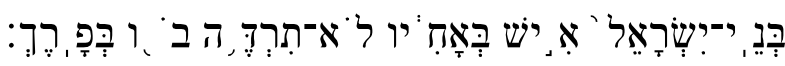

\section{Own translation with grammatical notes:}

44 Your male and female slaves are to come from the nations around you; from them you may buy slaves.

45 You may also buy some of the temporary residents living among you and members of their clans born in your country, and they will become your property.

46 You can will them to your children as inherited property and can make them slaves for life, but you must not rule over your fellow Israelites ruthlessly. 


\section{Context:}

Leviticus 25 provides for every seventh year to be dedicated to the Lord as a sabbath of rest (the so-called Sabbath Year). Every 50th year must be dedicated as the Year of Jubilee during which all Israelites are to return to their clans and property. The theological basis of this provision is that all the land belongs to the Lord and that the Israelites are aliens and the Lord's tenants (Lev. 25:23). Hebrew slaves are specifically included in these provisions of release from slavery.

\section{Interpretation:}

Whilst Hebrew slaves enjoyed legal protection and legally entrenched freedom after six years, non-Hebrew slaves (also called Canaanite slaves) were slaves in the common sense of the term. They were considered to be property first and foremost, and were enslaved for life if not set free by their owners.

Relevance for the exhortations directed at slave-owners in the New Testament:

It seems probable that the majority of slaves owned by Jews during the time of the New Testament were foreign slaves, and thus considered property.

Jewish law provided for remarkable protection of Hebrew slaves. An Israelite could sell himself to a fellow-Israelite because of poverty, but he was legally entitled to freedom after six years. These provisions are in stark contrast to the position of slaves under Greek and Roman law. Foreign slaves, however, were treated as property.

\section{The rights of slave-owners in respect of their slaves}

\subsection{Greek law}

\section{Plato: Leges. 3.690a-b}

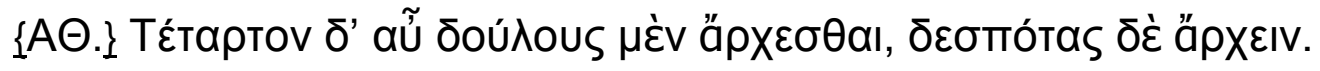

$\{K \wedge.\} \sqcap \tilde{\omega} \varsigma$ yà $\rho$ oü;

Own translation with grammatical notes:

Athenian: "Fourthly, on the one hand slaves ought to be ruled, and owners ought to rule."

Clinias: "Absolutely." [litt. "For how not?"]. 


\section{Context:}

In his Laws Plato (ca. 429-347 BC) deals with social morality as opposed to individual morality (Annas, 2003:1191). He has given up hope that an expert ruler could rule uncorrupted by power, yet maintains that political division and strife can only be overcome by complete obedience to the laws, since the laws are the product of rational reflection. Among these laws we find the one quoted above.

\section{Interpretation:}

The general principle is stated: owners rule over their slaves.

Relevance for the exhortations directed at slave-owners in the New Testament:

The general principle applies in owner-slave relationships in the New Testament: the owner rules over the slave.

\section{Demosthenes: In Evergum et Mnesibulum 47.72}

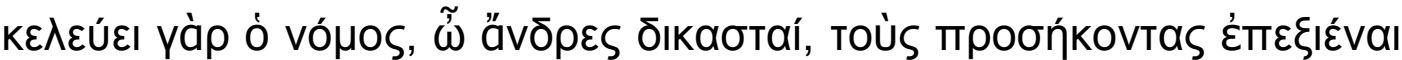

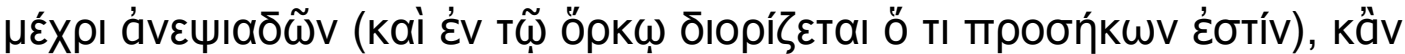

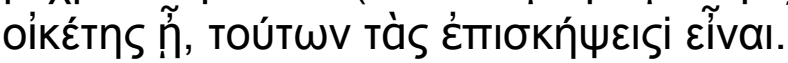

\section{Own translation with grammatical notes:}

For the law commands, honourable members of the jury, that relatives to the degree of cousins may prosecute (and that in the oath it will be determined what the relationship is), even if [the victim] is a servant, from which the denunciation will proceed.

i) Used in this context as a technical legal term for the first step in a prosecution (Liddell et al., 1996).

\section{Context:}

This private speech of Demosthenes (384-322 BC) states the law of Athens in relation to an owner's right to prosecute the perpetrator of a crime against the owner's slave.

\section{Interpretation:}

In the event of a crime perpetrated against a slave, the owner will have the right to institute a prosecution against the perpetrator. 
Relevance for the exhortations directed at slave-owners in the New Testament:

A slave-owner could institute action against the perpetrator(s) of a crime against his slave.

\section{Plato: Leges 9.865c (cf. 868a)}

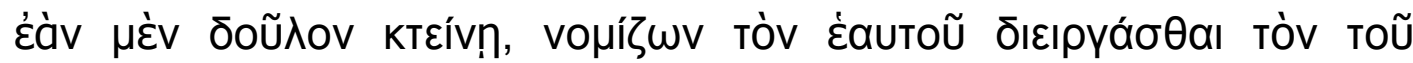

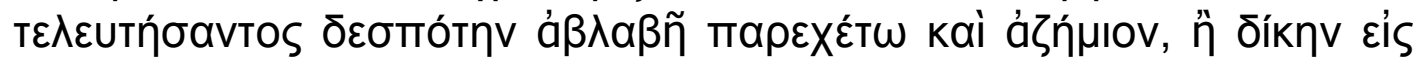

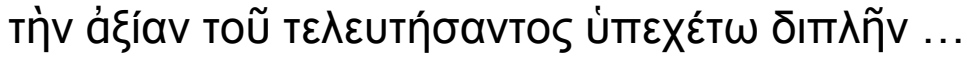

\section{Own translation with grammatical notes:}

Indeed, if he kills a slave, let him promise to the owner of the deceased to indemnify him against damage and loss, calculated customarily like a slave of his own, or let him be liable to a penalty for double value of the deceased.

\section{Context:}

In his Laws Plato (c. 429-347 BC) deals with social morality as opposed to individual morality (Annas, 2003:1191). He has given up hope that an expert ruler could rule uncorrupted by power, yet maintains that political division and strife can only be overcome by complete obedience to the laws, since the laws are the product of rational reflection. Among these laws we find the one quoted above.

\section{Interpretation:}

An owner is entitled to compensation from a perpetrator who kills his slave unlawfully (cf. Morrow, 1939:27).

Relevance for the exhortations directed at slave-owners in the New Testament:

In the event of the death of a slave, his owner would be entitled to compensation. 


\section{Demosthenes: In Aphobum 1. 27.9}

ò yà

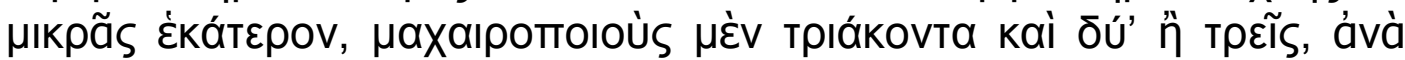

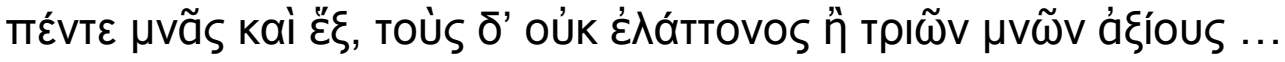

\section{Own translation with grammatical notes:}

For [my] father, honourable members of the jury, bequeathed two factories, each doing great business. The one was a weapon factory employing thirtytwo or thirty-three slaves, each worth five or six minae but none worth less than three minae ...

\section{Context:}

In this private speech Demosthenes (384-322 BC) establishes the value of a disputed estate.

\section{Interpretation:}

The slaves are clearly considered part of the property of the factory, and thus of the estate. And the slaves are bequeathed as part of the factory.

Relevance for the exhortations directed at slave-owners in the New Testament:

Slaves may have been bequeathed by their owners.

\section{Aristoteles: Politica 1255b. 9-15}

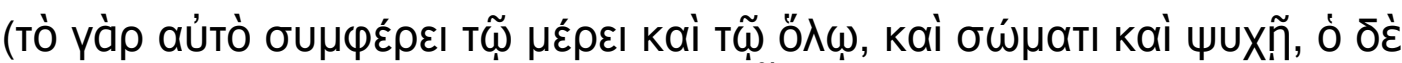

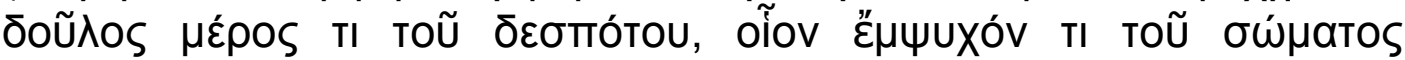

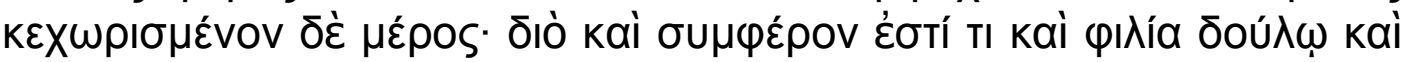

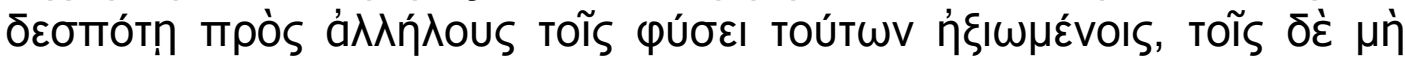

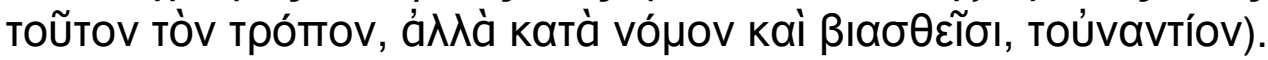

\section{Own translation with grammatical notes:}

(For this is useful to the part as well as the whole, to body as well as soul for the slave is a part of the owner, a uniquely living yet separate part of the body. Subsequently there is a certain harmony and friendship between slave and owner when deemed to be in their natural state, yet if they are not in this state but according to law and force, the opposite is true.) 


\section{Context:}

The Politica of Aristotle (ca. 435-335 BC) represents typical writings on political theory in ancient Greece and Rome (Nussbaum, 2003a:1206). He

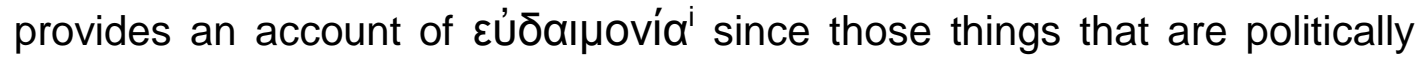
distributed such as property and offices are means to achieve human flourishing. He also considers various regimes in an attempt to identify the best form of government. Aristotle's statements on slaves must therefore first and foremost be considered in a political rather than legal context. This does, however, not necessarily imply that his statements on slavery, such as the one quoted above, are not juridically relevant and/or accurate. The above-quoted definition forms part of a section dealing with household management, and specifically the relationship between slave-owner and slave.

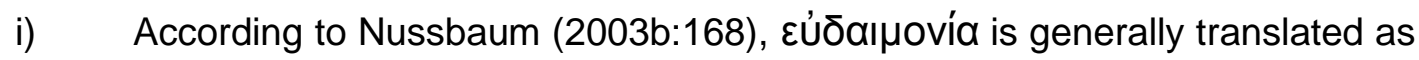
"happiness" but may be more accurately rendered "human flourishing".

\section{Interpretation:}

Aristotle admits that the relationship between owner and slave is not simply a legal relationship, but necessarily also functions on a personal level. The metaphor of the slave being a part of the owner's body seems to suggest that such a personal relationship does not detract in the least from the owner's legal rights with regard to his slave.

Relevance for the exhortations directed at slave-owners in the New Testament:

Whatever personal relationship an owner may have with his slave, does not interfere with his legal rights.

Greek law viewed the relationship between owner and slave from the viewpoint of power and authority. The owner had (with few exceptions) absolute power over his slave, like he did over his wife and children, and his property. He thus could lawfully sell, bequeath or in any other manner alienate his slaves, or claim compensation for damages to his slave-property. The owner's personal relationship with his slaves had no bearing on his legal rights. 


\subsection{Roman law}

Justinianus: Institutiones 1.8.1 (cf. Justinianus, Digesta 1.6.1.1)

In potestate itaque dominorum sunt servi. Quae quidem potestas iuris gentium est: nam apud omnes peraeque gentes animadvertere possumus dominis in servos vitae necisque potestatem ${ }^{\text {ii }}$ esse: et quodcumque per servum adquiritur, id domino adquiritur.

\section{Own translation with grammatical notes:}

Slaves are subject to the power of their owners. This power indeed derives from the lawi of nations. For equally among all nations we can observe that an owner has with regard to his slaves the right of life and death;i and that whatever is acquired by a slave belongs to his master.

i) Genitive of content.

ii) Potestas (ius) vitae necisque refers to the power or right of life or death that an owner had over his slave (Berger, 1953:534). This power also included the death penalty. Although the owner had to consult a council of relatives before imposing a severe penalty, he was not obliged to heed the council's advice.

\section{Context:}

Title 8 discusses those who are their own masters and those who are subjected to another person, namely slaves. The law is stated from the perspective of the owner and in terms of his rights rather than those of the slave.

\section{Interpretation:}

The basic principle is clearly stated namely that a slave-owner quite literally has the right of life and death over his slave. This dichotomy suggests the two extremes of a slave-owner's power over his slave, namely generosity on the one hand and force or the threat of force on the other (cf. Bradley, 1987:113).

Relevance for the exhortations directed at slave-owners in the New Testament:

Any conduct by a slave and/or slave-owner described in the New Testament must be considered in the light of the owner's right to the slave's life and death.

Roman law defined the rights of a slave-owner over his slave succinctly: He had the right of life and death, with very few exceptions. This principle is founded in the point of view that slaves were pro- 
perty, and thus subject to the (almost) absolute power and authority of their owners.

\subsection{Jewish law}

Jewish law does not stipulate precisely the rights of slave-owners. It is stated, however, explicitly in Leviticus 25:44-46 (see 4.3 above) that foreign slaves may be enslaved for life, and by implication thus treated like slaves in the Greek and Roman sense of the word.

\section{Constructing the rights and duties of slave-owners as legal context to the new testament}

Considering the evidence provided above, three conclusions may be drawn with regard to the legal context of passages on slavery in the New Testament. Firstly, the three legal systems under investigation did not vary much regarding the legal definitions of freedom and slavery, the legal status of slaves, and the rights of slave-owners in respect to their slaves.

Secondly, slaves were legally seen as property and thus subject to the absolute control of their owners. The fact that slaves were human beings were considered irrelevant to the law, since they were not deemed to be it by their own volition, but rather by that of their owners. This was also true of foreigners according to Jewish law in terms of which foreigners could be enslaved for life.

Thirdly, and most importantly, Jewish law did point to one deviation: Hebrew slaves were not to be considered slaves but rather labourers. They were legally entitled to freedom after six years without having to pay any compensation to their owners. This very progressive order for Hebrew slaves was founded in God's salvation of Israel from slavery in Egypt. Unlike the other legal systems, Jewish law was based on divine revelation. And having Israelites enslaved for life would have been contrary to God's revelation of his salvation of Israel. This unique status of Hebrew slaves provides a clue, if not yet evidence, that Jewish law with its theological foundation provided a sound alternative legal and religious context to the authors of the New Testament books, addressing Christian slave-owners. Scholars such as Flesher (1988:x) argue that the Mishnah and other Jewish law codes do not represent actual Jewish slave practices and are not historically reliable. Whilst this may be true, it does not exclude the possibility that the writers of the New Testament used Jewish law of slavery as a vehicle to promote a more flexible relationship between slave-owner and slave, irrespective of whether 
this relationship was actually realised or not. We submit that Jewish law of slavery may have functioned as a counterweight to the strict legal contexts provided by Greek and Roman law. This submission will have to be tested by way of philological analysis of the relevant New Testament passages.

\section{List of references}

ANNAS, J. 2003. Plato. Vol. 1. (In Hornblower, S. \& Spawforth, A., eds. The Oxford Classical Dictionary. 3rd rev. ed. Oxford: Oxford University Press. p. 1190-1193.)

ARISTOTELES. Politica. (In Anon. Thesaurus Linguae Graecae: a digital library of Greek literature. http://stephanus.tlg.uci.edu Date of access: 28 Sept. 2007.)

BARTCHY, S.S. 1973. First-century slavery and the interpretation of 1 Corinthians 7:21. Atlanta: Scholars Press. (SBL Dissertation Series, no. 11.)

BERGER, A. 1953. Encyclopedic Dictionary of Roman Law. Philadelphia: American Philosophical Society. (Transactions of the American Philosophical Society held at Philadelphia for promoting useful knowledge. New Series. Vol. 43, part 2.)

BHS. 1996. Biblia Hebraica Stuttgartensia: with Westminster Hebrew morphology. Stuttgart: German Bible Society. (Electronic ed.)

BORKOWSKI, A. \& DU PLESSIS, P. 2005. Textbook on Roman law. 3rd ed. Oxford: Oxford University Press.

BRADLEY, K.R. 1987. Slaves and masters in the Roman Empire: a study in social control. Oxford: Oxford University Press.

BUCKLAND, W.W. 1908. The Roman law of slavery: the condition of the slave in private law from Augustine to Justinian. Cambridge: Cambridge University Press.

CALHOUN, G.M. 1977. Introduction to Greek legal science. Ed. by F. de Zulueta. Aalen: Scientia.

CAWKWELL, G.L. 2003. Demosthenes. Vol. 2. (In Hornblower, S. \& Spawforth, A., eds. The Oxford Classical Dictionary. 3rd rev. ed. Oxford: Oxford University Press. p. 456-458.)

CROOK, J.A. 1984. Law and life of Rome, 90 BC-212 AD. New York: Cornell University Press.

DEMOSTHENES. In Timocratem. (In Anon. Thesaurus Linguae Graecae: a digital library of Greek literature. http://stephanus.tlg.uci.edu Date of access: 3 Oct. 2007.)

ELON, M. 1994. Jewish law: history, sources, principles. 4 vols. Trans. from the Hebrew by B. Auerbach and M.J. Sykes. Jerusalem: Jewish Publication Society.

FISHER, N.R.E. 1993. Slavery in classical Greece. Bristol: Bristol Classical Press. (Classical World Series.)

FLESHER, P.V.M. 1988. Oxen, women, or citizens? Slaves in the system of the Mishnah. Atlanta: Scholars Press. (Brown Judaic Studies, 143.)

GAIUS. 1935. Institutionum commentarii quattuor. Ed. by E. Sechel \& B. Kuebler. http://web.upmf-grenoble.fr/Haiti/Cours/Ak/ Date of access: 18 Sept. 2009. 
HARRISON, A.R.W. 1968. The law of Athens: the family and property. Oxford: Clarendon.

HEZSER, C. 2005. Jewish slavery in antiquity. Oxford: Oxford University Press.

HOMERUS. Ilias. (In Anon. Thesaurus Linguae Graecae: a digital library of Greek literature. http://stephanus.tlg.uci.edu Date of access: 1 Oct. 2007.)

JOHNSTON, D. 1999. Roman law in context. Cambridge: Cambridge University Press.

JUSTINIANUS. Digesta. (In Spruit, J.E., Feenstra, R. \& Bongenaar, K.E.M., eds. 1994. Corpus Iuris Civilis: teks en vertaling. Vol. 2-6. Zutphen: Walburg. 2:89; 3:38.)

JUSTINIANUS. Institutiones. (In Spruit, J.E., Feenstra, R. \& Bongenaar, K.E.M., eds. 1993. Corpus luris Civilis: teks en vertaling. Vol. 1: Institutiones. Zutphen: Walburg. p. 15-16, 23, 65.)

KELLY, J.M. 1992. A short history of Western legal theory. Oxford: Clarendon.

LIDDELL, H.G., SCOTT, R., JONES, H.S. \& MCKENZIE, R., eds. 1996. A Greek-English lexicon with a revised supplement. Oxford: Clarendon. [CD].

NUSSBAUM, M.C. 2003a. Political theory. (In Hornblower, S. \& Spawforth, A., eds. The Oxford Classical Dictionary. 3rd. rev. ed. Oxford: Oxford University Press. p. 1206-1207.)

NUSSBAUM, M.C. 2003b. Aristotle. (In Hornblower, S. \& Spawforth, A., eds. The Oxford classical dictionary. 3rd rev. ed. Oxford: Oxford University Press. p. 165-169.)

PLATO. Leges. (In Anon. Thesaurus linguae Graecae: a digital library of Greek literature. http://stephanus.tlg.uci.edu Date of access: 3 Oct. 2007.)

PRINGSHEIM, F. 1950. The Greek law of sale. Weimar: Hermann Böhlaus.

SIMPSON, D.P. 1959. Cassell's New Latin-English English-Latin Dictionary. London: Cassell.

SMYTH, H.W. 1956. Greek grammar. Rev. by G.M. Messing. Cambridge: Harvard University Press.

WATSON, A. 1987. Roman slave law. Baltimore: Johns Hopkins University Press.

WATSON, A. 1995. The spirit of Roman law. Athens: University of Georgia Press.

WESTERMANN, W.L. 1959. Slavery and the elements of freedom in ancient Greece. (In Finley, M.I., ed. Slavery in classical antiquity: views and controversies. Cambridge: Heffer. p. 17-32.)

WILLCOCK, M.M. 2003. Homer. (In Hornblower, S. \& Spawforth, A., eds. The Oxford classical dictionary. 3rd revised ed. Oxford: Oxford University Press. p. 718-720.)

ZANE, J.M. 1998. The story of law. 2nd ed. Indianapolis: Liberty Fund.

Key concepts:

New Testament

rights

slave-owners

slavery

slaves, duties regarding

\section{Kernbegrippe:}

Nuwe Testament

regte

slawe, verpligtings ten opsigte van

slawe-eienaars

slawerny 